Available online at GSC Online Press Directory

GSC Biological and Pharmaceutical Sciences

e-ISSN: 2581-3250, CODEN (USA): GBPSC2

Journal homepage: https://www.gsconlinepress.com/journals/gscbps

(RESEARCH ARTICLE)

\title{
Antibacterial and Antifungal activities of aqueous leaves extract of some medicinal plants
}

\author{
Oluwajobi Iyanuloluwa *, Kabiru Yusuf Adamu and Jigam A Audu \\ Department of Biochemistry, Federal University of Technology Minna, Nigeria.
}

Publication history: Received on 28 August 2019; revised on 30 September 2019; accepted on 01 October 2019

Article DOI: https://doi.org/10.30574/gscbps.2019.9.1.0185

\begin{abstract}
The aqueous leaves extracts of Psidium guajava, Vernonia amygdalina and Azadiracta indica were evaluated for phytochemical compositions, antibacterial and anti-fungi activities against microbial isolates. Ampicillin and vastatin were used as standards for antibacterial and antifungal assays respectively. All phytochemicals tested were present in the aqueous extract of the plants. Glycoside and anthraquinone were absent in methanol extract of $P$. guajava and $A$. indica respectively. Psidium guajava recorded the highest alkaloids $(6.40 \pm 0.35 \mathrm{mg} / \mathrm{g})$ and phenol $(18.63 \pm 0.29 \mathrm{mg} / \mathrm{g})$ while Azadirachta indica recoded the least. Vernonia amygdalina had the highest saponins $(6.63 \pm 0.34 \mathrm{mg} / \mathrm{g}) \mathrm{while}$ Azadirachta indica recoded the least $(2.40 \pm 0.34 \mathrm{mg} / \mathrm{g})$. However, Azadirachta indica had the highest tannin contents of $(23.52 \pm 0.25 \mathrm{mg} / 100 \mathrm{~g})$. Aqueous extract of Azadirachta indica had a greater zone of inhibition range between $10.00 \pm 0.10$ to $14.00 \pm 0.05 \mathrm{~mm}$ and $13.00 \pm 0.05$ to $14.00 \pm 0.05 \mathrm{~mm}$ against bacteria and fungi respectively. Psidium guajava show a lower activity against bacteria $(12.00 \pm 0.05 \mathrm{~mm})$ and higher antifungal activities $(11.00 \pm 0.05 \mathrm{~mm}$ and $19.00 \pm 0.05 \mathrm{~mm}$ ). Vernonia amygdalina on the other hand had $13.00 \pm 1.45 \mathrm{~mm}$ zone of inhibition against Streptococcus faecalis and Pseudomonas aeruginosa, and antifungal activities range between $9.00 \pm 0.35 \mathrm{~mm}$ and $15.00 \pm 0.45 \mathrm{~mm}$. In conclusion Azadiracta indica extract exhibited more antibacterial activities while Psidium guajava exhibited more antifungal activities than the other plant extracts. Therefore, more research should be carried out to enable the purification of the specific biopotential chemicals from these plants and their subsequent processing into antimicrobial agents in food industries.
\end{abstract}

Keywords: Azadiracta indica; Psidium guajava; Vernonia amygdalina; Antimicrobial

\subsection{Introduction}

Food safety is a global issue with significant implications to human health. The world health organization reports that, annually, unsafe food results in the illnesses of at least 2 billion people worldwide [1]. Some countries have made progress in controlling foodborne disease but the number of those affected by foodborne diseases is growing globally [2]. Fruits and vegetables are prone to several post-harvest losses due to diseases like bacterial rot, smut etc which in turn reduces the shelf-life of the fruits. Estimated post-harvest losses are about 25-30\% due to microbial spoilage [3]. Moreover, wastage of spoilt fruits and vegetables can lead to scarcity and famine

From ancient times, a large number of plants and herbs have been used in traditional medicines against bacterial infection [4]. The uses of plant and herb extracts as antimicrobial agents in food and soft drinks have also been reported for centuries [5]. Due to potential toxicity of chemical food preservatives, there has been increased demand for food preservatives from natural sources [3]. This has led researchers and food processors to come across natural food additives with a wide range of antimicrobial activities. As a result today plant antimicrobial products have acquired importance in food system to retard bacterial and fungal growth [6]. Consumer interest is also increasing in

\footnotetext{
${ }^{*}$ Corresponding author

E-mail address: iyanuloluwaoluwajobi@gmail.com
} 
consumption of food products having natural ingredients. Several studies have reported the use of natural molecules i.e. organic acids, peptides and essential oils in past several years [7].

Azadiracta indica (Neem or dongoyaro) leaves has antibacterial properties and could be used for controlling airborne bacterial contamination of food substances in the residential premises [8]. The Neem seed has also been used as traditional medicine to treat microbial infections. The aqueous extract of Neem has a powerful chemotherapeutic and viral agent [9]

Psidium guajava (Guava) belongs to the family Myrtaceae and is considered to have originated from tropical South America. Guava tree grow in tropical and sub-tropical area of the world like Asia, Africa and Hawaii [10] Psidium guajava is a phytotherapic plant used in folk medicine that is believed to have active components that help to treat and manage various infectious diseases [11]. The many parts of the plant have been used in traditional medicine to manage conditions like malaria, gastroenteritis, vomiting, diarrhea, dysentery, wounds, ulcers, toothache, coughs, sore throat, inflamed gums, and a number of other conditions [12]. Its leaf contains copious amounts of phenolic phytochemicals which inhibit peroxidation reaction in the living body, and therefore can be expected to prevent various chronic diseases such as diabetes, cancer, heart-disease [13]. Guava is rich in tannins, phenols, triterpenes, flavonoids, essential oils, saponins, carotenoids, lectins, vitamins, fiber and fatty acids. The leaves of guava are rich in flavonoids and phenols.

Vernonia amygdalina commonly called bitter leaf is a perennial shrub belonging to the family Asteraceae [14]. Traditionally, this plant is used for treatment of stomach disorder, skin wound, swelling, diarrhea, scabies, hepatitis, ascarasis, tonsillitis, fever, mastitis, tapeworm and worms infection [15] Considering the antimicrobial reputations of these plants, the present study was aimed to evaluate antibacterial and anti-fungi activities of aqueous leaves extracts of these medicinal plants against microbial isolates from spoilt fruit.

\subsection{Material and methods}

\subsection{Collection of plant}

Spoilt tomato fruits (Lycopersicum esculentum) were gotten from Kure market in Minna, Niger. The leaves of Veronia amygladina (bitter leaf), Azadirachta indica (Neem plant), Psidium Guajava (Guava leaves) were collected from Green farms in Niger state and identified by a plant taxonomist in Federal University of Technology, Minna. The plants were brought to the laboratory and rinsed with water to remove the soil particles. Then air dried at room temperature.

\subsection{Sources of microorganisms}

Bacteria isolates including; Klebsiella pneumonaie, Pseudomonas aeruginosa, Microccocus roseus and Streptococcus faecalis, and fungi including; Trichophyton tonsurans, Aspergillius niger and Candida tropicalis were cultured and isolated from spoilt tomatoes and bell pepper fruit according to the methods of Egofure et al. [16].

\subsection{Extraction of crude extract}

A $50 \mathrm{~g}$ of accurately weighed plant powder was put into a round bottom flask containing $250 \mathrm{mls}$ of distilled water. This was then boiled for 2 hours at a temperature. It was then cooled and filtered using a whatman filter paper. The filtrate was then concentrated in a water bath and stored for further use.

\subsection{Qualitative and quantitative screening for secondary metabolites}

The plant extract was analyzed for the presence of some secondary metabolite including alkaloids, terpenes, tannins, saponins, phenols, steroids, phlobatannins and flavonoids using standard procedures [17-19]. Quantitative analysis was conducted for flavonoid, alkaloids, total phenol, tannin and saponins using standard procedures [20]

\subsection{Antibacterial and anti-fungal Activity}

The plate-hole diffusion assay as described by Ieven et al. [21] was used to determine the zone of inhibition of bacteria (antibacterial activity) by plant crude aqueous extracts. The selected microorganisms obtained was maintained at $4^{\circ} \mathrm{C}$ on nutrient agar plates before use. Using a sterile cork-borer of $5 \mathrm{~mm}$ diameter, five holes per plate were made into the set agar containing the bacteria culture. A total of 7 drops $(40 \mathrm{mg} / \mathrm{ml}, 80 \mathrm{mg} / \mathrm{ml}$ and $120 \mathrm{mg} / \mathrm{ml})$ of the different plant extracts were poured into the wells and one contained distilled water and ampicillin $(50 \mathrm{mg} / \mathrm{ml})$. The plates were placed in the incubator at $37^{\circ} \mathrm{C}$ for $12 \mathrm{hrs}$. Antibacterial activity was recorded in millimeters [22, 23]. This was also done for 
isolated fungi to know the antifungal activity of the extracts. Ampicillin was used as standards for antibacterial assay, while vastatin was used as standards for antifungal assay.

\subsection{Statistical analysis}

Values were analyzed using statistical package for social science (SPSS) version 21 and presented as means \pm SE of the mean. Comparisons between different groups were carried out by one-way analysis of variance (ANOVA) followed by Duncan's Multiple Range Test (DMRT). The level of significance was set at $P<0.05$.

\subsection{Results}

\subsection{Qualitative phytochemical composition}

The phytochemical composition of the aqueous and methanol leaves extracts of Psidium guajava, Vernonia amygdalina and Azadirachta indica presented in Table 1. All phytochemicals tested were present in the aqueous extract of the plants. Glycoside and anthraquinone were absent in methanol extract of $P$. guajava and $A$. indica respectively. All other phytochemicals tested were present in the methanol extract of the three (3) plants.

Table 1 Qualitative phytochemical compositions of Aqueous and methanol Extracts of Psidium guajava, Vernonia amygdalina and Azadirachta indica

\begin{tabular}{|c|c|c|c|c|c|c|}
\hline \multirow[b]{2}{*}{ Plants } & \multicolumn{3}{|c|}{ Aqueous extract } & \multicolumn{3}{|c|}{ Methanol extract } \\
\hline & $\begin{array}{c}P . \\
\text { guajava }\end{array}$ & V. amygdalina & $\begin{array}{c}A . \\
\text { indica }\end{array}$ & $\begin{array}{c}P . \\
\text { guajava }\end{array}$ & V. amygdalina & $\begin{array}{c}A . \\
\text { indica }\end{array}$ \\
\hline Flavonoid & + & + & + & + & + & + \\
\hline Saponin & + & + & + & + & + & + \\
\hline Alkaloids & + & + & + & + & + & + \\
\hline Tannins & + & + & + & + & + & + \\
\hline Phenols & + & + & + & + & + & + \\
\hline Glycosides & + & + & + & - & + & + \\
\hline Anthraquinone & + & + & + & + & + & - \\
\hline
\end{tabular}

\subsection{Quantitative phytochemical compositions}

The quantitative phytochemical composition of aqueous extract of leaves of Psidium guajava, Vernonia amygdalina, and Azadirachta indica presented in Table 2. Psidium Guajaza recorded the highest alkaloids $(6.40 \pm 0.35 \mathrm{mg} / \mathrm{g})$ and phenol $(18.63 \pm 0.29 \mathrm{mg} / \mathrm{g})$ while Azadirachta indica recoded the least. Vernonia amygdalina had the highest saponins $(6.63 \pm 0.34 \mathrm{mg} / \mathrm{g})$ while Azadirachta indica recoded the least $(2.40 \pm 0.34 \mathrm{mg} / \mathrm{g})$. However, Azadirachta indica had the highest tannin contents of $(23.52 \pm 0.25 \mathrm{mg} / \mathrm{g})$.

Table 2 Quantitative constituents of Psidium guajava, Vernonia amygdalina, and Azadirachta indica

\begin{tabular}{llllll}
\hline Plants & $\begin{array}{l}\text { Saponin } \\
\text { (mg/g) }\end{array}$ & $\begin{array}{l}\text { Alkaloids } \\
\text { (mg/g) }\end{array}$ & $\begin{array}{l}\text { Tannins } \\
\text { (mg/g) }\end{array}$ & $\begin{array}{l}\text { Flavonoids } \\
\text { (mg/g) }\end{array}$ & $\begin{array}{l}\text { Phenols } \\
(\mathbf{m g} / \mathbf{g})\end{array}$ \\
\hline Psidium guajava & $3.38 \pm 0.78^{\mathrm{b}}$ & $6.40 \pm 0.35^{\mathrm{c}}$ & $11.84 \pm 0.23^{\mathrm{b}}$ & $11.75 \pm 0.21^{\mathrm{a}}$ & $18.63 \pm 0.29^{\mathrm{b}}$ \\
Vernonia amygdalina & $6.63 \pm 0.34^{\mathrm{c}}$ & $2.44 \pm 0.34^{\mathrm{b}}$ & $8.19 \pm 0.32^{\mathrm{a}}$ & $11.29 \pm 0.05^{\mathrm{a}}$ & $17.14 \pm 0.38^{\mathrm{ab}}$ \\
Azadirachta indica & $2.40 \pm 0.34^{\mathrm{a}}$ & $1.68 \pm 0.22^{\mathrm{a}}$ & $23.52 \pm 0.25^{\mathrm{c}}$ & $17.19 \pm 0.29^{\mathrm{b}}$ & $16.00 \pm 0.27^{\mathrm{a}}$ \\
\hline \multicolumn{5}{c}{ Data are Mean SEM of triplicate determination. Data followed by different superscript alphabets are significantly different $\mathrm{P}<0.05}$.
\end{tabular}

\subsection{Antibacterial and antifungal activities of aqueous extract of Azadirachta indica (Dogonyaro) leaves}

Antibacterial and antifungal activities of aqueous extract of Azadirachta indica (Neem) leaves are presented in Table 3. Aqueous extracts of Azadirachta indica had a greater zone of inhibition on Pseudomonas aeruginosa (12.00 \pm 0.40 to $14.00 \pm 0.15 \mathrm{~mm})$, Klebsiella pneumonaie $(12.00 \pm 0.05$ to $14.00 \pm 0.05 \mathrm{~mm}$ ) and Micrococcus roseus (10.00 \pm 0.10 to $14.00 \pm 0.05 \mathrm{~mm}$ ). But when compared to ampicillin (positive control), there was an appreciable zone of inhibition 
$(15.00 \pm 0.25$ to $25.00 \pm 0.45 \mathrm{~mm})$ than the aqueous extracts. Aqueous extract of Azadirachta indica however, had no effect on Trichophyton tonsurans and Aspergillius niger but inhibited the growth of Candida tropicalis $(13.00 \pm 0.05$ and $14.00 \pm 0.05 \mathrm{~mm}$ ).

Table 3 Antibacterial and Antifungal Activities of Aqueous Extract Azadirachta indica (Neem) Leaves

\begin{tabular}{|c|c|c|c|c|c|}
\hline Concentration of extracts & $40 \mathrm{mg} / \mathrm{ml}$ & $80 \mathrm{mg} / \mathrm{ml}$ & $120 \mathrm{mg} / \mathrm{ml}$ & $\begin{array}{l}\text { Ampicillin } \\
(50 \mathrm{mg} / \mathrm{ml})\end{array}$ & DMSO \\
\hline \multicolumn{6}{|l|}{ BACTERIA } \\
\hline Klebsiella pneumonaie & $13.00 \pm 0.05^{b}$ & $12.00 \pm 0.05^{\mathrm{ab}}$ & $14.00 \pm 0.05^{b}$ & $25.00 \pm 0.45^{b}$ & - \\
\hline Microccocus roseus & $10.00 \pm 0.10^{\mathrm{a}}$ & $13.00 \pm 0.25^{b}$ & $14.00 \pm 0.05^{b}$ & $15.00 \pm 0.25^{\mathrm{a}}$ & - \\
\hline Streptococcus faecalis & $12.00 \pm 0.09^{\mathrm{ab}}$ & $11.00 \pm 0.55^{\mathrm{a}}$ & $12.00 \pm 0.10^{\mathrm{a}}$ & - & - \\
\hline Pseudomonas aeruginosa & $13.00 \pm 0.50^{\mathrm{b}}$ & $14.00 \pm 0.15^{b}$ & $12.00 \pm 0.40^{\mathrm{a}}$ & - & - \\
\hline FUNGI & & & & $\begin{array}{l}\text { Vastatin } \\
67 \mathrm{mg} / \mathrm{ml}\end{array}$ & DMSO $\epsilon$ \\
\hline Trichophyton tonsurans & - & - & - & $20.00 \pm 0.45$ & - \\
\hline Aspergillius niger & - & - & - & $15.00 \pm 0.25$ & - \\
\hline Candida tropicalis & $14.00 \pm 0.05$ & $13.00 \pm 0.05$ & - & - & - \\
\hline
\end{tabular}

\subsection{Antibacterial and antifungal activities of aqueous extract of Psidium guajava (Guava) leaves}

Antibacterial and antifungal activities of crude aqueous extract Psidium guajava (Guava) leaves as presented in Table 4. Aqueous Extract of Psidium guajava (Guava) Leaves were not active against Klebsiella pneumonaie and Pseudomonas aeruginosa but show little activity against Microccocus roseus $(12.00 \pm 0.05 \mathrm{~mm}$ ) and Streptococcus faecalis $(12.00 \pm 0.05$ $\mathrm{mm}$ ). The extract demonstrated anti-fungal activity range between $11.00 \pm 0.05 \mathrm{~mm}$ and $19.00 \pm 0.05 \mathrm{~mm}$ against Trichophyton tonsurans, $10.00 \pm 0.05$ to $16.00 \pm 0.05 \mathrm{~mm}$ against Aspergillius niger and $7.00 \pm 0.05 \mathrm{~mm}$ to $15.00 \pm 0.05 \mathrm{~mm}$ against Candida tropicalis.

Table 4 Antibacterial and Antifungal Activities of Aqueous Extract of Psidium guajava (Guava) Leaves

\begin{tabular}{|c|c|c|c|c|c|}
\hline Concentration of extracts & $40 \mathrm{mg} / \mathrm{ml}$ & $80 \mathrm{mg} / \mathrm{ml}$ & $120 \mathrm{mg} / \mathrm{ml}$ & $\begin{array}{l}\text { Ampicillin } \\
(50 \mathrm{mg} / \mathrm{ml})\end{array}$ & DMSO \\
\hline \multicolumn{6}{|l|}{ BACTERIA } \\
\hline Klebsiella pneumonaie & - & - & - & $25.00 \pm 0.45^{b}$ & - \\
\hline Microccocus roseus & - & - & $13.00 \pm 0.05^{\mathrm{a}}$ & $15.00 \pm 0.25^{\mathrm{a}}$ & - \\
\hline Streptococcus faecalis & - & - & $12.00 \pm 0.05^{a}$ & - & - \\
\hline Pseudomonas aeruginosa & - & - & - & - & - \\
\hline FUNGI & & - & - & $\begin{array}{l}\text { Vastatin } \\
67 \mathrm{mg} / \mathrm{ml}\end{array}$ & $\operatorname{DMSO}(-)$ \\
\hline Trichophyton tonsurans & - & $11.00 \pm 0.05^{b}$ & $19.00 \pm 0.05^{b}$ & $20.00 \pm 0.05$ & - \\
\hline Aspergillius niger & $10.00 \pm 0.05$ & $11.00 \pm 0.05^{b}$ & $16.00 \pm 0.05^{\mathrm{a}}$ & $15.00 \pm 0.05$ & - \\
\hline Candida tropicalis & - & $7.00 \pm 0.05^{\mathrm{a}}$ & $15.00 \pm 0.05^{\mathrm{a}}$ & - & - \\
\hline
\end{tabular}

Values are mean \pm SEM of 3 determinations

\subsection{Antibacterial and antifungal activities of aqueous extract of Vernonia amygdalina leaves}

Antibacterial and antifungal activities of crude aqueous extract of Vernonia amygdalina leaves as presented in Table 5. Aqueous Extract of Vernonia amygdalina leaves were not active against Micrococcus roseus but show little activity 
against Klebsiella pneumonaie (13.00 $\pm 1.45 \mathrm{~mm}$ ) Streptococcus Faecalis and Pseudomonas aeruginosa. The extract also demonstrated antifungal activities against Trichophyton tonsurans $(12.00 \pm 0.00 \mathrm{~mm})$, Aspergillius niger $(9.00 \pm 0.35 \mathrm{~mm}$ to $13.00 \pm 0.10 \mathrm{~mm}$ ) and Candida tropicalis $(13.00 \pm 0.05 \mathrm{~mm}$ and $15.00 \pm 0.45 \mathrm{~mm})$.

Table 5 Antibacterial and antifungal activities of crude aqueous extract of vernonia amygdalina (bitter leaf) leaves

\begin{tabular}{|c|c|c|c|c|c|}
\hline $\begin{array}{l}\text { Concentration } \\
\text { BACTERIA }\end{array}$ & $40 \mathrm{mg} / \mathrm{ml}$ & $80 \mathrm{mg} / \mathrm{ml}$ & $120 \mathrm{mg} / \mathrm{ml}$ & $\begin{array}{l}\text { Ampicillin } \\
50 \mathrm{mg} / \mathrm{ml}\end{array}$ & DMSO \\
\hline Klebsiella pneumonaie & - & $13.00 \pm 1.45^{b}$ & - & $25.00 \pm 0.15^{b}$ & - \\
\hline Micrococcus roseus & - & - & - & $15.00 \pm 0.55^{\mathrm{a}}$ & - \\
\hline Streptococcus Faecalis & - & $10.00 \pm 0.55^{\mathrm{a}}$ & $10.00 \pm 0.55^{\mathrm{a}}$ & - & - \\
\hline Pseudomonas Aeruginosa & - & $12.00 \pm 0.10^{\mathrm{ab}}$ & $12.00 \pm 0.24^{b}$ & - & - \\
\hline FUNGI & & & & $\begin{array}{l}\text { Vastatin } \\
\text { (Positive) } \\
67 \mathrm{mg} / \mathrm{ml}\end{array}$ & $\begin{array}{l}\text { DMSO } \\
\text { (Negative) }\end{array}$ \\
\hline Trichophyton tonsurans & - & - & $12.00 \pm 0.00^{\mathrm{a}}$ & $20.00 \pm 0.15$ & - \\
\hline Aspergillius niger & - & $9.00 \pm 0.35^{\mathrm{a}}$ & $13.00 \pm 0.10^{\mathrm{a}}$ & $15.00 \pm 0.55$ & - \\
\hline Candida tropicalis & - & $13.00 \pm 0.05^{b}$ & $15.00 \pm 0.45^{b}$ & - & - \\
\hline
\end{tabular}

\subsection{Discussion}

Plants serves as vegetables and are used the preparation of food nutritive seasoning used in the preparation of food. Apart from its nutritive value, plants have been found to contains bioactive metabolites with potentials to inhibit the growth of microorganisms [24]. In this study, Psidium guajava, Vernonia amygdalina and Azadirachta indica was found to contain high amounts of flavonoids in addition to other phytochemicals like tanins, saponins, phenols and alkaloids (Table 4.1), these findings agree with the workers [25-27], on phytochemical constituents of Psidium guajava, Vernonia amygdalina and Azadirachta indica. The bioactivity of medicinal plants has been linked to the presence of phytochemicals [28]

Researchers have also studied the phytochemical and antimicrobial properties of leaf of Vernonia amgdalina. Phytochemicals present in Vernonia amygdalina included flavonoids, cardiac glycosides, reducing sugar, terpenoids, saponins, anthraquinones, alkaloids and steroids as shown in table 1. These phytochemicals were present in both aqueous and methanol extract. Akinjogunla et al. [29] reported the presence of Carbohydrates, saponins, flavonoid and phlobatannin in $V$. amygdalina extracts.

Aqueous Extract of Vernonia amygdalina leaves were not active against Micrococcus roseus but show little activity against Klebsiella pneumonaie (13.00 $\pm 1.45 \mathrm{~mm}$ ) Streptococcus Faecalis and Pseudomonas aeruginosa. The extract also demonstrated antifungal activities against Trichophyton tonsurans $(12.00 \pm 0.00 \mathrm{~mm})$, Aspergillius niger $(9.00 \pm 0.35 \mathrm{~mm}$ to $13.00 \pm 0.10 \mathrm{~mm})$ and Candida tropicalis $(13.00 \pm 0.05 \mathrm{~mm}$ and $15.00 \pm 0.45 \mathrm{~mm})$. This finding is in agreement with earlier work by Udochukwu et al. [30], who reported the phytochemical and antibacterial activity of Vernonia amygdalina. However, Evbuomwan et al. [31] reported that the ethanol extract of $V$ amygdalina had higher zones of inhibition ranged from $8.0 \pm 2.0 \mathrm{~mm}$ at $25 \mathrm{mg} / \mathrm{ml}$ to $12.5 \pm 1.5$ at $200 \mathrm{mg} / \mathrm{ml}$ against $P$. aeruginosa; $9.0 \pm 1.0 \mathrm{~mm}$ at $50 \mathrm{mg} / \mathrm{ml}$ to $15.0 \pm 1.5 \mathrm{~mm}$ at $200 \mathrm{mg} / \mathrm{ml}$ against $S$ aureus. The discrepancy observed in the activities could be attributed to the variations in the dissolution capacity of the different solvents which in turn affected the degree of phytochemicals extracted [32]. The resistance of $V$ amygdalina to Micrococcus roseus may have arisen from drug/phytochemical inactivating enzymes present in the bacteria. Also, variations observed in the susceptibility of Gram positive and negative bacteria could have resulted from their relative composition of cell wall components [33]. Hence, the activities of the Vernonia amygdalina extract, especially the could confirm the traditional use of the plants against Eczema [34], wounds [35] and typhoïd fever [36]. The previous studies also verified the antimicrobial activities of the plant extracts against Staphylococcus epidermidis, Enterococcus faecalis, Staphylococcus aureus, Salmonella typhimurium, Salmonella typhi and Pseudomonas aeruginosa [37]. 
Several authors have established the potential of neem extracts and their components as antifungal agents. Govindachari et al. [38] The present study revealed that Azadirachta indica leaves possessed good anti-bacterial and anti-fungal activity better than the two other plant tested, confirming the great potential of bioactive compounds and rationalizing the use of this plant in primary health care [39]. The extracts of Neem when used as medicinal plant, could be useful for the growth inhibition of the harmful fungus. Investigating the antimicrobial effect of the plant extract in this study involved a comparison of their effect with commercially developed antibiotics and by comparing the inhibition it was observed that the commercial antibiotics had a larger inhibitory effect than the plan extracts. This is not surprising and reinforces the position that commercially perfected and tested antibiotics should be used in treatments whenever available [40]

The results of the present study shows similarities to the findings of Nwanneka et al. [41]which investigated the antimicrobial activity of Psidium guajava leaf extract, the results showed that both aqueous and ethanol extracts of guava leaf inhibited the growth of the bacteria and fungi tested but the ethanolic extract showed stronger inhibition than the aqueous extract against the organisms. The finding of this study was also inconformity with that of Pandey and Shweta [42], where the results of antibacterial activity of Psidium guajava leaf and stem reveals that methanol extract showed stronger anti-bacterial activity than aqueous extract [43].

\section{Conclusion}

This research work has shown that Vernonia amygdalina, Psidium guajava and Azadiracta indica has potential bioactive phytochemicals that are responsible for their antibacterial and antifungal activities. It has also proven that Azadiracta indica leaf was more potent against bacteria while Psidium guajava was more active against fungi than the other plants tested. Therefore, more research should be carried out to enable the purification of the specific biopotential chemicals and their subsequent processing into chemotherapeutic agents.

\section{Compliance with ethical standards}

\section{Acknowledgments}

Oluwajobi Iyanuloluwa wish to thanks the Technical and Laboratory Staff Biochemistry and Microbiology Department, Federal University of Technology Minna, for their assistance during the lab work.

\section{Disclosure of conflict of interest}

No conflict of interest exists.

\section{References}

1. World Health Organization (2004), International Classification of Diseases and related health problems, 10th Revision (ICD-10). Geneva, Switzerland World Health Organization.

2. World Health Organization (2014). Antimicrobial resistance: global report on surveillance, World Health Organization, Geneva.

3. Roopa,V.M and Suvarna,V.C. (2014). Biopreservation of Onions Using Plant Extracts and Antagonistic Organisms. Indian Journal of Applied Research, 4(6).

4. Okoli AS and Iroegbu CU. (2004). Evaluation of extracts of Anthocleista djalonesis, Nauclea latifolia and Uvaria afzalii for activity against bacterial isolates from cases of non-gonococcal urethritis. Journal of Ethanopharmacology, 92, 135-144.

5. Gulmez M, Oral N, Guven A, Vatansever L and Baz E. (2003). Antibacterial activity of oregano tea and a commercial oregano water against Escherichia coli 0157:H7, Listeria monocytogenes 4b, Staphylococcus aureus and Yersinia enterocolitica 03. International Journal of Food Science, 8, 7-13.

6. Souza EL, Lima EO, Freire KRLCP and Sousa KRL. (2005). Inhibition action of some essential oils and phytochemicals on the growth of moulds isolated from foods. Brazil Archive of Biology Technology, 2, 245-250.

7. Barreteau H, Mandoukou L, Adt I, Gaillard I, Courtois B and Courtois J. (2004). A rapid method for antimicrobial properties determination of natural molecules. Journal of Food Protection, 67, 1961-1964. 
8. Saseed AK and Junaid A. (2008). Study on the effect of Neem Azhadirachta indicaleaves smoke incontrolling airborne Bacteria in Residential premises. Current research in Bacteriology, 12, 64-66.

9. Hassan Amer, Wafaa A. Helmy and Hanan AA Taie. (2010). In vitro Antitumour activities of seeds and leaves Neem Azadirachta indicaextracts. International journal of Academic research. 22, 165-171.

10. Biswal B, Kimberly FM, Dwaye D and Anand Y. (2013). Antimicrobial activityof leaf extracts of Guava (Psidium guajava) on two Gram positive and two Gram negative bacteria. International Journal of Microbiology, 2, 7.

11. Abdelrahim SI, Almagboul AZ, Omer MEA and Elegami A. (2002). Antimicrobial activity of Psidium guajava L. Fitoterapia, 73(7-8), 713-715.

12. Begum S, Hassan SI, Ali SN and Siddiqui BS. (2004). Chemical constituents from the leaves of Psidium guajava. Natural Product Research, 18(2), 135-140.

13. El-Ahmady SH, Ashour ML and Wink M. (2013). Chemical composition and anti-inflammatory activity of the essential oils of Psidium guajava fruits and leaves. The Journal of Essential Oil Research, 25(6), 475-481.

14. Ijeh II and CECC Ejike. (2011). Current perspectives on the medicinal potentials of Vernonia amygdalina del. J. Med. Plant Res., 5, 1051-1061.

15. Farombi EO and O Owoeye. (2011). Antioxidative and chemopreventive properties of Vernonia amygdalina and Garcinia biflavonoid. Int. J. Environ. Res. Public Health, 8, 2533-2555.

16. Egofure, A.M., Bala, U., and Tina, Y.M. (2015). Screening for antimicrobial activities of some plants. Advance journal of food science and Technology, 4(7), 23-25.

17. Sofowora AE. (1993). Recent trends in research into African medicinal plants. J Ethnopharmacol, 389, $209-14$.

18. Harborne JB. (1993). Phytochemical Methods; A guild to modern Techniques to plant anaylsis Freeman and Company. NY, 78-80.

19. Trease GE and Evans WC. (1989). Pharmacognosy. 11th ed. London: Brailliar Tiridel CanMacmillan Publishers, 6075.

20. AOAC. (Association of official analytical chemist) (2000). Official Method analytical chemist, Washinton, D.C.

21. Juven BJ, Kanner J, Schved F and Weisslowicz H. (1994). Factors that interact with the antibacterial action of thyme essential oil and its active constituents. Journal of Applied Bacteriology, 76(6), 626-631.

22. Vlietinck AJ, Van-Hoof L, Totté J, Lasure A and Vanden BD. (1995). Screening of hundred Rwandese medicinal plants for antimicrobial and antiviral properties. Journal of Ethnopharmacology, 46, 31-47.

23. Yusuf AA, Lawal B, Yusuf MA, Omonije YO, Adejoke AA, Raji FH and Wenawo DL. (2018). Free Radical Scavenging Antimicrobial Activities and Effect of Sub-Acute Exposure to Nigerian Xylopia Aethiopica Seed Extract On Liver and Kidney Functional Indices of Albino Rat Iranian journal of toxicology ,12 (3), 51-58.

24. Akinjogunla OJ, Adegoke AA, Udokang IP and Adebayo-Tayo BC. (2009). Antimicrobial potential of Nymphaea lotus (Nymphaeaceae) against wound pathogens. J. Med. Plants Res, 3(3), 138-141.

25. SaiRam M, Ilavazhagan G, Sharma SK, Dhanraj SA, Suresh B, Parida MM and Selvamurthy W. (2000). Anti-microbial activity of a new vaginal contraceptive NIM-76 from neem oil (Azadirachta indica). Journal of Ethnopharmacology, 71(3), 377-382.

26. Sasidharan VK, Krishnakumar T and Manjula CB. (1998). Antimicrobial activity of nine common plants in Kerala, India. Philippine Journal of Science, 7, 34-41.

27. Nwafor IB, Amadi ES, Nwaziri AA and Nwuzo AC. (2007). Preliminary antimicrobial activities of crude Extract of some medicinal plants on Otitis media pathogen. In Proceedings of Annual Conference, Biotechnology Society of Nigeria (BSN), 17-79.

28. Asase A, Akwetey GA and Achel DG. (2010). Ethnopharmacological use of herbal remedies for the treatment of malaria in the Dangme West District of Ghana. Journal of ethnopharmacology, 129(3), 367-376.

29. Akinjogunla OJ, Ekoi OH, Odeyemi AT, Akinjogunla OJ, Etok CA and Oshoma CE. (2011). Preliminary phytochemistryand in-vitro antibacterial efficacy of Hydro-Ethanolic leaf extracts of Psidium guajava on common urinary tract bacterial pathogens. Biores. Bull, 5, 329-336. 
30. Udochukwu, U, Omeje FI, Uloma IS, Oseiwe FD. (2015). Phytochemical analysis of Vernonia amygdalina and Ocimum gratissimum extracts and their antibacterial activity on some drug resistant bacteria. American Journal of Research Communication, 3(5) 225-235

31. Evbuomwan L, Chukwuka EP, Obazenu EI and Ilevbare L. (2018). Antibacterial Activity of Vernonia amygdalina Leaf Extracts against Multidrug Resistant Bacterial Isolates. J. Appl. Sci. Environ. Manage. January, 22(1), 17.

32. Lawal B., Ossai P. C., Shittu O.K. and Abubakar A.N (2014).Evaluation of Phytochemicals, Proximate, Minerals and Anti-Nutritional Compositions of Yam Peel, Maize Chaff and Bean Coat. International Journal of Applied Biological Research. 6(2):01-17

33. Ibrahim TA, Lola A, Adetuyi FO and Jude-Ojei B. (2009). Assessment of the antibacterial activity of Vernonia amygdalina and Ocimum gratissimum leaves on selected food borne pathogens. Inter. J. Third World Med, 8 (2), 2324.

34. Regassa R. (2013). Assessment of indigenous knowledge of medicinal plant practice and mode of service delivery in Hawassa city, southern Ethiopia. J. Med. Plants Res., 7, 517-535.

35. Giday M, Z Asfaw and Z Woldu. (2009). Medicinal plants of the Meinit ethnic group of Ethiopia: An ethnobotanical study. J. Ethnopharmacol, 124, 513-521.

36. Bii C, KR Korir, J Rugutt and C Mutai. (2010). The potential use of Prunus africana for the control, treatment and management of common fungal and bacterial infections. J. Med. Plants Res., 4, 995-998.

37. Bolou GEK, I Bagre, K Ouattara and AJ Djaman. (2011). Evaluation of the antibacterial activity of 14 medicinal plants in Cote d'Ivoire. Trop. J. Pharmaceut. Res., 10, 335-340.

38. Govindachari TR, Suresh G, Gopalakrishnan G, Masilamani S and Banumathi B. (2000). Antifungal Activity of Some Tetranortriterpenoids. Fitoterapia, 71, 317-320.

39. Saradhajyothi K and Subbarao B. (2011). Antimicrobial potential of the extracts of the leave of Azadirachta indica, Linn. Nat Sci Biol, 31 65-69.

40. Gonçalves FA, Andrade Neto M, Bezerra JNS Macrae A Sousa OV Fonteles-Filho AA and Vieira RHSF. (2008). Antibacterial activity of guava, Psidiumguajava Linnaeus, leaf extracts on diarrhea-causing enteric bacteria isolated from Seabob shrimp. Xiphopenaeus kroyeri (Heller). Rev. Inst. Med. trop. S. Paulo, 50(1), 11-15.

41. Nwanneka LO, Ndubuisi M, Chikere N, Michael M and Oluwakemi A. (2013). Genotoxic and antimicrobial studies of the leaves of Psidium guajava.Euro-Asian Journal of Bio-Sciences Eurasia J Bio-Sci 7, 60-68.

42. Pandey A and Shweta S. (2011). Antifungal properties of Psidium guajavaleaves andfruits and fruits against various pathogens.Journal of Pharmaceutical and Biomedical Science.

43. Emmanuel OA. (2010). Antimicrobial activity profile of the constituents of four Ghanian aromatic medicinal plants. Kwame Nkuruma University, Ghana.

\section{How to cite this article}

Oluwajobi I, Kabiru YA and Jigam AA. (2019). Antibacterial and antifungal activities of aqueous leaves extract of some medicinal plants. GSC Biological and Pharmaceutical Sciences, 9(1), 62-69. 